DOI: 10.18778/2084-140X.09.37

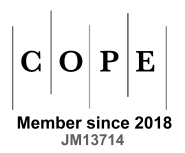

JM13714
J1

\title{
Girolamo Arnaldi, Federico Marazzi, Tarda Antichità e Alto Medioevo in Italia [Late Antiquity and Early Middle Ages in Italy], Viella, Roma 2017, 232 pp.
}

In 2017, the Italian publishing house Viella released a volume entitled Tarda Antichità e Alto Medioevo in Italia (Late Antiquity and early Middle Ages in Italy), written by two renowned researchers - Girolamo Arnaldi ${ }^{1}$ and Federico Marazzi ${ }^{2}$. The authors set themselves the task of creating an innovative synthesis of the history of Italy from the times of Diocletian up to the $11^{\text {th }}$ century that would depart from the traditional dates used to mark the beginning and the end of individual periods in that part of history ${ }^{3}$. In their opinion, the strict separation of the late Antiquity from the early Middle Ages is artificial, and a proper understanding of the transition between those eras requires knowledge of their

\footnotetext{
${ }^{1}$ Girolamo Arnaldi (1929-2016) - Italian historian, professor at the University of Bologna and the University of La Sapienza in Rome. His main area of interest was early medieval papacy. His most important works include: Le origini dello Stato della Chiesa, Torino 1987; Natale 875. Politica, ecclesiologia. Cultura del papato altomedievale, Roma 1990.

${ }^{2}$ Federico Marazzi (1962-) - Italian historian and archaeologist, professor at the Suor Orsola Benincasa University in Naples. Initially he was mainly interested in the history of the papacy in the late Antiquity and early Middle Ages, and then turned his attention to the archaeology of early medieval monasteries and southern history in the early Middle Ages. His most important works include the monograph Le città dei monaci. Storia degli spazi che avvicinano a Dio, Milano 2015.

${ }^{3}$ Syntheses of early Italian history usually begin with the Lombard invasion or Ostrogothic rule. A good example of such an approach is the first volume of the monumental Storia d' Italia edited by Giuseppe Galasso: P. Delogu, A. Guillou, G. Ortalli, Longobardi e Bizantini, Torino 1980.
}

mutual relations. The work was intended as a concise, footnote-free textbook, focusing not on a detailed description of facts, but on the historical processes taking place at that time, and on their political, economic, social and cultural background. Having read the volume, we can declare that these tasks have been successfully accomplished.

The first part of the work, written by Arnaldi and entitled simply Late Antiquity (Tarda Antichità, p. 11-72), consists of seven short chapters covering the period from the crisis of the third century up to the fall of the Western Empire. While in substantive terms the text is of a very high quality, one allegation can be made against it from the point of view of the subject matter declared in the title of the paper. In fact, it is a synthesis that presents a general transformation of the entire empire rather than the situation of Italy itself, although this is obviously also the case. Although in his afterword Federico Marazzi mentions that Arnaldi's original idea was to write a book which would focus on the events taking place in Italy as an illustration of certain general processes. The co-author seems to have failed to notice, however, that strictly Italian topics take up relatively little space in this part of the book compared to the general outline of the situation of the Roman Empire, augmented with many examples not related to the Apennine Peninsula. It is, therefore, at odds with the title of the work and with the principles presented in the introduction. However, the sad circumstances surrounding the work may provide some justification. Girolamo Arnaldi died before the text was published and the book had to be finished by Marazzi, who 
admitted that his deceased mentor may have planned to modify his part of the volume, but did not manage to do so in time.

The first chapter of the first part - Looking back: the crisis of the third century (Uno sguardo all indietro: la crisi del III scolo, p. 14-22) - covers, somewhat contrary to its title, not only the crisis of the third century, but also the transformations taking place from the time of Octavian August to the time of the Illyrian emperors. The author focuses on the evolution of the Roman military model. During the period in question, there was a shift from treating Italy as an exclusive reservoir of recruits for the legions towards basing the core of the army on the inhabitants of other provinces. This phenomenon accelerated the Romanization of those territories. In cases of increased threat and instability of the central government, however, it led to an increase in local particularisms, which was clearly exemplified by the events of the $3^{\text {rd }}$ century.

The second chapter, entitled Diocletian's Reforms (Le riforme di Diocleziano, p. 22-31), contains a concise description of the circumstances in which the emperor came to power and the characteristics of his most important reforms (administrative reforms - creating dioceses and increasing the number of provinces, military reform). A lot of focus was devoted to the ruler's economic policy, which was assessed as not achieving the expected results. In the author's opinion, Diocletian's reign was a turning point in the history of the empire, even considering that the ruler had a negative attitude towards phenomena that would soon become crucial for the image of the empire in the late Antiquity, namely Christianization and Hellenization.

In the third chapter - Constantine and the Christian Roman Empire (Constantino e l'impero romano cristiano, p. 31-44) - Arnaldi presented the evolution of the position of Christians within the empire until their religion became privileged. He considered the decision to issue the 313 Tolerance Edict necessary in order to eliminate the harmful divergence between the state and the growing number of Christian communities, which were marginalized be- cause they did not fit into the traditional Roman approach to relations between power and worship. Over the course of the fourth century, the relations between the state and the Church evolved from the initial model of close cooperation to the emergence of significant discrepancies, with the recognition of Christianity as a state religion during the reign of Theodosius the Great. The status of bishops grew significantly, they began to oppose the authorities more boldly, and the concepts of imperium and sacerdotium started to clash more and more often.

Chapter Four, The Germanics and the Huns: the Great Migration of Peoples (Germani e Unni: la grande migrazione di popoli, p. 44-53), provides a brief overview of the events concerning the barbarians' migration to the empire from the crossing of the Danube by the Goths in 376 to the second decade of the fifth century, when the Germanic peoples (Visigoths, Suebi, Vandals, Alans, Burgundians) relatively stabilized their presence in the western part of the empire.

The fifth chapter, The Germanics within the empire (I Germani nell'Impero, p. 53-59), which describes the barbarians' actions in the western part of imperium until the 470s, is similar. This section contains information about the Vandal expansion in Africa, the Hun threat, the progress made by the Visigoths and the decomposition of the Roman rule in Gaul.

Chapter Six - Two Cities (Le due città, p. 59-67) - deals with the growing differences between the western and eastern parts of the empire, described mainly by the example of the position of the Church. While in the east there was still a strong imperial power strongly associated with the Church (although it should be noted that the heresies that emerged there, such as Monophysitism or Nestorianism, assumed an anti-state character once they had been condemned by the ruler), in the west bishops often had to take action against the barbarians, thus becoming principal leaders of local communities. In the west, this situation was conducive to the deepening of the conviction that imperium and sacerdotium were separate and the growing emancipatory aspirations of the papacy, as evidenced by the doctrine of 
superiority of spiritual power over secular power formulated by Pope Gelasius.

The seventh (and final) chapter of this part of the work, entitled The Fall of the Empire in the West (La caduta dell'Impero d'Occidente, p. 68-72), is a brief reflection on the real meaning of the year 476 for the ancient world. According to the author, it was undoubtedly a new situation when Italy, core of the empire, for the first time found itself under the barbarian rule. In fact, the process of transition from antiquity to the Middle Ages was, however, continuous. Its causes date back to earlier times, and the fall of Romulus Augustus did not in any way mean the end of this process. In Arnaldi's opinion, Byzantium carried on the Roman tradition only to a very limited extent, representing a culture that was already profoundly modified in various ways and Hellenized.

The second part of the work, entitled Early Middle Ages (Alto Medioevo, p. 73-194) and written by Federico Marazzi, is slightly longer than the first and includes 11 chapters, covering the period from the reign of Odoacer up to the $11^{\text {th }}$ century. Marazzi's text can in no way be accused of being incompatible with the title of the book and the declarations in the introduction, since it focuses on the situation in Italy.

In the first chapter - The reign of Odoacer and the Ostrogothic rule (Le dominazioni di Odoacre e degli Ostrogoti, p. 73-78) - the author briefly describes the rule in Italy, first by Odoacer and then by Ostrogoths, emphasizing that the year 476 was in fact not as important for those who lived then as it was for later generations. It merely meant that Italy was reduced to a rank similar to that of other western provinces ruled by barbarian kings, and was not treated as the end of the imperial power, which, after all, was doing well in Constantinople. At that time, however, social and urban changes were taking place in Italy, making its landscape increasingly different from the ancient one.

The second chapter - Crisis of the Ostrogothic Kingdom and war with the Eastern Roman Empire (La crisi del Regno degli Ostrogoti e la guerra con l'Impero Romano d'Oriente, p. 78-82) - provides a brief description of Justinian's
Gothic wars and the events in Italy immediately preceding them. The effects of the re-conquest were considered catastrophic - although Italy was reintegrated into Imperium, it was economically destroyed and had no chance to play a central role within the empire, becoming a peripheral province.

Marazzi devoted the third chapter, Lombards and Byzantines between the $6^{\text {th }}$ and $7^{\text {th }}$ centuries (Longobardi e Bizantini fra VI e VII secolo, p. 83-95), to the circumstances surrounding the arrival of Lombards in Italy, the stabilization of their kingdom, and the evolution of the Byzantine strategy towards the peninsula. Imperium, which treated Italy peripherally, initially only maintained key inland territories (Rome, Ravenna) and coastal areas that were easy to defend and provide with supplies. The situation changed in the times of Constans II, with the rise of the Arab threat. The Byzantines would henceforth only consider keeping control over the southern part of Italy significant (as manifested by the 663 Benevento expedition), which was necessary to prevent the Arabs from seizing West Mediterranean and opening up another front against the Empire.

Chapter Four - The Lombard identity in the face of Italian reality (L'identita Longobarda di fronte alla realta italiana, p. 96-116) - concerns the changes in Lombard society that took place during the $7^{\text {th }}$ century and the process of consolidating the royal power. The author notes that funeral rites or certain legal provisions testified to the fact that the Germanic invaders had a rather strong need to emphasize their distinctiveness (however, elites that identified with the Lombardian heritage should not be treated in terms of strictly understood ethnicity), although the latter eventually begun to fade away, succumbing to the influence of Roman culture. This was manifested by the adaptation of the Latin language and the final adoption of Christianity in the Catholic version by the Lombards at the end of the $7^{\text {th }}$ century.

In Chapter Five - Society and economy of the Lombard Kingdom (Societa ed economia del Regno longobardo, p. 116-122) - Marazzi briefly described the economy of Italy, which was based on agriculture and slowly 
developing trade, during the period when the Lombard kingdom flourished.

Chapter Six - From Liutprand to Desiderius: the pinnacle and crisis of the Lombard Kingdom and the acknowledgement of the papacy as a new political entity (Da Liutprando a Desiderio: l'apogeo e la crisi del Regno longobardo e l'affermazione del papato come nuovo soggetto politico, p. 122-138) - concerns the aggressive policy pursued by kings Liutprand, Ratchis, Aistulf and Desiderius against Byzantine properties in Italy and the papacy. Marazzi notes that the adoption of Catholicism provided the Lombards with legitimacy to renew their claims to rule over the whole of Italy, especially in view of the fact that it coincided with the emergence of iconoclastic controversy in Byzantium. The aggressive actions of the Lombardian monarchs accelerated the process of emancipation of the papacy, which (despite the religious conflict) for a long time was hesitant to abandon its dependence on the emperor completely. The passivity of Constantinople, increased pressure from Lombardy and attempts of the Italian population to gain autonomy ultimately led to the independence of the Holy See and to a new force - the Franks - being involved in the affairs of Italy.

The seventh chapter - Charlemagne's invasion of Italy and the political landscape up to the end of the $8^{\text {th }}$ century (La discesa di Carlo Magno in Italia e lo scenario politico sino alla fine dell' VIII secolo, p. 138-150) - is devoted to the consequences of the establishment of the Frankish rule in Italy, following Charlemagne's invasion against the Kingdom of Lombards in 774 and the overthrow of Desiderius. The imperial coronation of Charlemagne was a clear attempt to make a direct reference to the heritage of Roman emperors and, in the opinion of the Frankish ruler, did not constitute an act of recognition of the superiority of the papal authority. In that period, the division of Italy into the northern and southern part, which had already been outlined, became established. The Frankish ruler did not show much interest in subjugating the south of the peninsula, which was difficult to control, thus providing the princes of Benevento and the remaining Byzantine properties with an opportunity to keep their independence.
In the eighth chapter Italy at the beginning of the $9^{\text {th }}$ century: economic and social portrait (L'Italia all'inizio del IX secolo: il quadro economico e sociale, p. 150-158) - Marazzi briefly describes the economy of Carolingian Italy, characterized by the development of maritime trade, conducted by centers such as Venice and Naples, and by the prosperity of agriculture in the inland part of the country.

The ninth chapter - Southern Italy between the $9^{\text {th }}$ and $11^{\text {th }}$ centuries: from the Arab invasion of Sicily to the Norman conquest of the south (L'Italia meridionale fra IX e XI secolo: dall' invasione araba della Scicilia alla conquista normanna del Mezzogiorno, p. 158-171) - includes an outline of the history of southern Italy between the $9^{\text {th }}$ and $11^{\text {th }}$ centuries. The author emphasizes the importance of the Arab expansion for the history of the region and the ambiguous attitude of the southern trade centers. Although the unstable situation of the Principality of Benevento and the succession dispute that led to its fragmentation made it easier for Muslims to explore the southern part of the peninsula (eagerly pursued given the difficulty in conquering Byzantine Sicily) in the $9^{\text {th }}$ century, thanks to the efforts of Carolingian Emperor Louis II and Byzantium, the emirates established there were eradicated quite quickly. However, Sicily remained in Arab hands until the $11^{\text {th }}$ century. The chief tendency characteristic for the south in the $10^{\text {th }}$ and $11^{\text {th }}$ centuries was the progressive defragmentation of the remains of the Principality of Benevento and the temporary strengthening of the position of Byzantium. Both those phenomena ended with the Norman conquests.

The tenth chapter - From Regnum Langobardorum to Regnum Italiae: Central-Northern Italy from mid- $9^{\text {th }}$ to late $10^{\text {th }}$ century (Dal Regnum Langobardorum al Regnum Italiae: l'Italia centro-settentroniale dalla meta del IX alla fine del X secolo, p. 171-183) Marazzi describes the deterioration of the royal power of the Carolingians, the seizure of the Lombard crown by representatives of the local aristocracy, and the progressive feudal fragmentation and autonomy of elites. The author notes that although those phenomena were undoubtedly the result of the fact that royal authority 
had been gradually weakening since the death of Charlemagne, they cannot be interpreted solely in terms of the decomposition of the state. At that time, the idea of a highly centralized monarchy did not exist in Western Europe and even strong rulers relied on representatives of the elite, who had a great deal of freedom of action and were closely linked to the territories they governed.

Chapter Eleven - Political, social and cultural transformations in the decades following 1000 (Transformazioni politiche, sociali e culturali nei decenni successivi al Mille, p. 183-194) - presents the circumstances in which German kings bound themselves to Italy and the changes that their actions there brought. The author considers the very negative views on $10^{\text {th }}$ century popes to be exaggerated, although it cannot be denied that at the time the Holy See was controlled by local aristocrats who only protected their own interests. German rulers generally left quite a lot of freedom to the Italian elite. The $11^{\text {th }}$ century saw changes so important to the peninsula that it could be regarded as the end (fluid and extended over time, of course) of the early Middle Ages in Italy. By the mid-century, the papacy was emancipated and a dispute with the imperial authorities began, which reverberated for a long time after. The foundations of future cities-republics also emerged and economic development accelerated. Thanks to the participation in the First Crusade, centers such as Pisa and Venice became trade powers not just locally, but with much broader significance. According to Marazzi, those transformations made the $12^{\text {th }}$ century reality of Italy vastly different from the reality of previous centuries.

Apart from the two main parts, the volume by Girolamo Arnaldi and Federico Marazzi includes the above-mentioned foreword (p. 7-9) and afterword (p. 194-199) by Marazzi, genealogical tables (p. 201-204), principal bibliography (p. 205-219) and indices of persons (p. 221-224), names of peoples and political-institutional units (p. 225-226), as well as places (p. 227-231).

The book is a highly valuable work from the scholarly point of view. Nevertheless, there are some problematic elements. On page 43, for example, Arnaldi gives the date of the massacre that Theodosius the Great committed against the people of Thessaloniki as 399 , while the event is believed to occur in $390^{4}$. On page 134 , in turn, Marazzi describes Pepin the Short as $f u$ turo re dei Franchi (the future king of Franks), which must be surprising given that this fragment concerns the times of the pontificate of Stephen II (in that context, the author seems to refer to the year 753), i.e. after 751, when the coronation of Pepin as king is believed ${ }^{5}$ to have taken place, only repeated by that pope in 754 . The author mentions immediately afterwards that Stefan only confirmed the anointing given to the ruler by St. Boniface (in doing so, Boniface confirmed the transfer of the royal power to Pepin by the congregation of Frankish lords). However, Marazzi does not mention 751 nor any other date. Referring to Boniface's act, he only uses the vague phrase qualche tempo prima (some time earlier - by default before Stephan's confirmation). All this means that although Marazzi is undoubtedly aware of the repeated coronation, his argument does not indicate at what point he places the first one and whether he has a different view on this subject than the customary opinion, namely the year 751 .

However, the examples given above are minor and incidental, and as such cannot affect the highly positive assessment of work. Nor can the latter be unduly lowered by the more serious allegation, already discussed, that the section on Antiquity is somewhat incompatible with the title and the principles set out in the introduction. In any case, this accusation does not in any way concern the part devoted to the early Middle Ages.

\footnotetext{
${ }^{4}$ Cf. e.g. G. Friell, S. Williams, Theodosius. The Empire at Bay, London 2005, p. 48; M.N. PAWLAK, Cesarstwo rzymskie od Walentyniana $I$ do Teodozjusza I (363-395), [in:] Świat rzymski w IV wieku, ed. P. Filipczak, R. Kosiński, Kraków 2015, p. 168. ${ }^{5}$ Cf. e.g. R. McKitterick, The Frankish Kingdoms under the Carolingians, 751-987, London-New York 1983, p. 33-38; I. Wood, The Merovingian Kingdoms 450-751, London-New York 1994, p. 290-293.
} 


\section{BIBLIOGRAPHY}

Arnaldi G., Natale 875. Politica, ecclesiologia. Cultura del papato altomedievale, Roma 1990.

Arnaldi G., Le origini dello Stato della Chiesa, Torino 1987.

Delogu P., Guillou A., Ortalli G., Longobardi e Bizantini, Torino 1980.

Friell G., Williams S., Theodosius. The Empire at Bay, London 2005.

Marazzi F., Le città dei monaci. Storia degli spazi che avvicinano a Dio, Milano 2015.

McKitterick R., The Frankish Kingdoms under the Carolingians, 751-987, London-New York 1983.
PAWLAK M.N., Cesarstwo rzymskie od Walentyniana I do Teodozjusza I (363-395), [in:] Świat rzymski w IV wieku, ed. P. Filıpczak, R. KosıńsKi, Kraków 2015.

Wood I., The Merovingian Kingdoms 450-751, London-New York 1994.

Maciej Dawczyk (Łódź) ${ }^{*}$ (iD) https://orcid.org/0000-0003-0639-7101

Translated by Katarzyna Gucio

${ }^{*}$ University of Łódź, Faculty of Philosophy and History, Department of Byzantine History 